\title{
Reassembling Weber to reveal the-past-as-history in management and organization studies
}

Organization $0(0) 1-19$

(C) The Author(s) 2013

Reprints and permission: sagepub.co.uk/journalsPermissions.nav DOI: I0.1 I77/|3505084|3475495 org.sagepub.com @SAGE

\section{Albert J Mills \\ Saint Mary's University, Canada \\ Terrance G Weatherbee \\ Acadia University, Canada}

\section{Gabrielle Durepos}

St. Francis Xavier University, Canada

\begin{abstract}
The purpose of this article is to unravel the link between the past and history to reveal the importance and the problems of developing a historically informed critical management studies (Booth and Rowlinson, 2006; Kieser, 1994). Drawing on Munslow (2010), we focus on the relationship between 'the past' and 'history' as 'ontologically dissonant' (p. 3) to argue for an 'epistemically skeptical,' relational approach to critical organizational history. These arguments are explored through analysis of the 'career' of Max Weber in management and organization studies (MOS).
\end{abstract}

\section{Keywords}

epistemic phase, historiography, history, knowledge, relationalism, Weber

\section{Turning MOS with history}

The most recent appeal for MOS scholars to engage more with history in their research (Rowlinson et al., 2009) has been coined the 'call' for an 'historic turn' (Clark and Rowlinson, 2004). This entreaty is the culmination of almost two decades of ongoing assertion that MOS suffers because

\section{Corresponding author:}

Albert J Mills, Sobey School of Business, Saint Mary's University, 903 Robie Street, Halifax, Nova Scotia, Canada B3H $3 \mathrm{C} 3$

Email: albert.mills@smu.ca 
of its ahistorical character (Booth and Rowlinson, 2006; Kieser, 1994; Pettigrew et al., 2001; Zald, 1993). While much of the debate lies beyond the scope of this article (for a more detailed discussion see Bryman et al., 2011; Durepos and Mills, 2012a; Rowlinson, 2004), we focus on those epistemic aspects that deal specifically with notions of the past.

While there are far-reaching epistemological differences between those calling for more engagement with history (cf. Rowlinson, 2004; Usdiken and Kieser, 2004), proponents for the historic turn generally agree on a need to problematize issues of presentism (i.e. viewing organizations as existing in 'a decontextualized extended present'), universalism (i.e. viewing organizational phenomena as valid across societies and time), scientism (i.e. privileging scientific accounts of organizations) and methods of analysis (i.e. the types of approach used to study organizations).

Much less discussed is the problematic link between history and the past, although Rowlinson (2004: 11) has argued that as 'a result of its inherent ambiguity, history has almost always had to tackle epistemological questions, such as "How can we know about the past? What does it mean to explain historical events?"”.

For Rowlinson (2004: 10) 'history is the study, not of past events that are gone forever from perception, but rather "traces" of those events'. He adds, "these "traces" are the raw materials of the historian's discourse, rather than the events themselves' (Rowlinson, 2004). Rowlinson (2004)

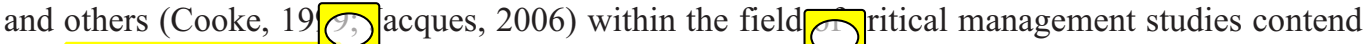
that the issues raised by call for the 'historic turn' rai lestions that are fundamental to the character and direction of MOS as a whole.

These varied arguments revolve around the problematic of 'knowledge' of the 'past' and the lessons we may learn for the production of 'knowledge' per se in MOS. The most thoroughgoing attempt to lay out these linkages has been that of Booth and Rowlinson (2006), whose 'agenda' includes calls for 'alternative methods and diverse styles of writing appropriate for studying organization historically', greater attention to the work of philosophers of history (particularly Foucault and White) and more reflection on 'the link between the history of management thought and the teaching of management and organization theory' (p. 5). Arguing that business schools have been cut off from humanistic thinking, Booth and Rowlinson (2006: 7) contend that the historic turn should also involve 'more critical and ethical reflections'.

However, there has been little concerted effort to surface 'the past' and its relationship(s) to history and we argue that this lacuna threatens to derail any reflective potential or liberationary intent when engaging with the historic turn. To explain the bases of our concern, we have turned to the recent debates within History; debates which call for a thorough 'rethink' of that field, and which provide an important set of insights concerning the relationship(s) between the past, history, and our own rethink in MOS. First, as the mediation of our intellectual projects stem from an unreflexive default to 'common-sense' ideas of the past, we have absented the effects of historical consciousness (Lukacs, 1968; Rusen, 2004) as a mode of thinking. This means we often ignore, or fail to understand, our actions undertaken as unconscious historians and our role-complicity in creating 'history' through the knowledge production efforts of actor-networks embedded in socio-political contexts (Durepos and Mills, 2012a). In a similar vein, Kalela (2012), speaking from within the discipline of History, argues that historians need to take account of the 'social process of historymaking' (p. 1) and the influence of things like popular and public histories on the making of scholarly histories. In short, 'history-making [is] a basic social practice' (p. 2) that influences how 'history' is constructed.

Second, and relatedly, as History and MOS have taken distinctly separate paths in their development and constitution as disciplines (Weatherbee, 2012), this has resulted in significant intellectual and theoretical differences with respect to how the past itself is viewed. Despite the influences of 
the linguistic/narrative impulses on theoretical positions within History, there still has been a general failure in MOS to fully recognize or problematize the ontological differences between the 'past' and 'history', 'event' and 'representation' (Munslow, 2010). The conflation of the 'past' with 'history' has significant implications for how we distinguish between and understand the interplay of the factive and narrative elements of our research and disciplinary knowledge. Finally, we argue, that these two conditions mask the ontological politics (Mol, 1999) and enactment of historymaking within MOS itself. In this respect we fail to recognize that we are part of actor-networks who bring about socio-material effects in the world (Law and Mol, 1995); both in our discipline and in society at large.

As we will argue below, questions about the relationship between the past and history raise epistemic concerns that have hitherto been missing from the call for the historic turn. While we sympathize with the earlier factual (Wren, 1979) and contextual (Keiser, 1994) stages in the call for a historic turn we argue that the factual and realist approaches reduce history to an atheoretical search for facts and their constitution as 'context'; approaches that tend to compound the problem of ahistorical theories of organization with atheoretical accounts of history.

Similarly our sympathy with the more recent methodological stage in the call for a historic turn (Booth and Rowlinson, 2006) is tempered by a concern that history is conflated with the past and thus ultimately remains a realist project whose plausibility if not accuracy can be explored through the right methods. Thus, in proposing what we call an epistemic stage of the historic turn we are simultaneously reproducing what we see as the spirit of the debate (ways of representing and respecting the past) while developing a thoroughgoing critique of any notion of history that serves to reify the past-as-history. To paraphrase Mills and Durepos (2010: 26), 'we set out to simultaneously represent and destabilize past events with the aim of pluralizing history'.

\section{Lessons from History}

Across the social sciences and humanities, it was the influence of the linguistic turn which first breached the ramparts solidly erected in History by mainstream scientific based approaches to historiography (Jenkins, 1991; White, 1973). White's 'Meta-History' (1973) is generally credited as leading the first comprehensive assault on the dominant style of history; using issues of narrative as the theoretical lever. The subsequent debates in History (the discipline) about history (the subject) were oriented upon the problematics of representation, specifically, on the ontological and epistemological basis underlying the mainstream modernist, i.e. scientific and empiricist, concepts of past and of history (Iggers, 1997). These culminated with a call for a 'rethink of history' (Jenkins, 2003), which occurred at roughly the same time as MOS scholars were arguing for a historic turn.

The 'rethink' involved a questioning of the basis of conventional history, focusing on issues of narrative form (Zagorin, 1999), representation (Ankersmit, 1998), ethics (Fay, 2004), aesthetics (Jenkins, 1997b) and the nature of 'the past' distinct and apart from 'history' (Munslow, 2010). The growing recognition of the differences between narrative history and the actuality of the past has significant theoretical implications for the practice of historiography (Iggers, 1997). In brief, historians informed by the linguistic/narrative turn began to question the historical practices that treated history and the past as synonymous. They argued that as the past was ontologically unrecoverable (Iggers, 1997; Munslow, 2010) and since it was narrative which, in part, ordered and disciplined historical facts, a unitary representation or 'truth' of the past based upon fact was an unattainable goal. The scientific basis for belief in representational correspondence between historical fact and lived reality was challenged in the view that the past is of a different ontological status than history (Iggers, 1997); that history and the past are 'ontologically dissonant' (Munslow, 
2010: 3), that the past is 'ultimately inaccessible' (Jenkins, 1997b: 61). In Munslow's (2010: 37) words, "We cannot be "in touch" with the past in any way that is unmediated by historiography, language, emplotment, voice, ideology, perspective or physical and/or mental states of tiredness, ennui, and so on'.

In focusing on the ontological dissonance between the past and history Munslow and other poststructuralist historians have had to confront the difficult problem of realism and fact. Neither Muslow (2010) nor Jenkins (1997b) deny that people and events in the past once had an ontologically real status. Max Weber, for example, was a real person who wrote several books at given times. However, those 'facts' alone do not constitute history; they have to be ordered by a narrative account that is shaped by the historian and such things as the conventions of narrative construction. As Jenkins (1997b: 61) summarizes the issue:

[We] might thus say that the past as constituted by its existing traces is always apprehended and appropriated textually through the sedimented layers of our previous interpretations and through the reading habits and categories developed by our previous/current methodological practices. And whilst we suspect that there may well be a 'real past' (an actual past) metaphorically underlying all our disparate versions of it, we 'know' that that past, that 'real referent', is ultimately inaccessible, and that all we have are our versions but that that hardly matters, since versions are all we've ever had.

Thus, while we can speak of 'factual knowledge' (Munslow, 2010) as reference to somethings that existed, we cannot reproduce those things or their meanings. Indeed, as Nietzsche argued long before 'there are no facts in themselves. It is always necessary to begin by introducing a meaning in order that there can be a fact' (quoted in Brown, 2005: 102). In short, 'form (history) always precedes content (the past)'(Munslow, 2010: 44).

This suggests to us that an epistemic approach is now needed in order to advance the historic turn; one which stands in contrast to the factual, contextual, and methodological phases that have characterized the debate so far.

The factual phase consists of a number of accounts throughout MOS that assume that if organization studies were to take account of the facts revealed by history then a number of erroneous assumptions would be undermined' (Rowlinson, 2004: 8). Wren $(1972,1979)$ exemplifies this approach. It is an approach, however, which assumes that history is a representation of the facts of the past, and largely downplays the role of narrative in the social construction of historical accounts.

The contextual phase, focusses on the importance of historical context, arguing that organizational studies can be enriched by taking into account the elements of the past that constitute the 'context' in which organizational phenomena are studied. Kieser (1994) exemplifies this approach. However, as Goldman (1994) has pointed out, in this approach the notion of culture and history are often used interchangeably to capture the idea of context; that context is under-theorized. Further, we would argue, context is also conflated with the past and in a somewhat fixed and concrete nature, i.e. that the past is there to be uncovered in its relationship to extant organizational phenomena. Like the factual phase of the debate, the contextual phase fails to question the problematic nature of organizational studies (Goldman, 1994).

The methodological phase focusses on the production or crafting processes of history, arguing that history has to be understood as the outcome of genres of writing and philosophical means of adjudicating historical knowledge. Booth and Rowlinson (2006) exemplify this approach. Developed from a critical perspective, the methodological phase of the debate involves a thoroughgoing critique not only of historiography but also of management and organization studies. Through 
a focus on knowledge as the outcome of particular methodological stances, this approach fundamentally questions the dominant scientifistic character of organizational studies and related historical accounts. It also suggests a new, epistemic phase in the historic turn focused on the assembly of knowledge (Latour, 2005).

The epistemic phase is not so much a radical departure from, as an outgrowth of, the methodological phase. It seeks to move the historical turn beyond accounts of knowledge of the past (and of the present) to understandings of the assembly of knowledge (Latour, 2005). This phase is exemplified in the work of Durepos and Mills (2012b) and Weatherbee et al. (2012). Starting with Munslow's (2010) argument that the conflation of the past and history creates 'the-past-as-history', the focus here is on how notions of 'the-past-as-history' come to constitute knowledge; knowledge not simply of the past but of the present.

In moving debate towards an epistemic phase we both embrace and distance ourselves from poststructuralist accounts in History. We maintain that the dualist nature of relativist-realist positioning fails to adequately, and simultaneously, address two issues of direct concern to any historical project - (i) empirical evidence or traces of the past and (ii) the nature of representations. Like Foucault, we wish to occupy the space between positivist knowledge and the subjectivities that produce them (Knights, 2002). To do this we must account for a past world inclusive of persons, activities and events (the evidence thereof), as well as for the ontological difference between these persons, activities and events and interpretive renditions of them in historical narrative(s) (their representations). Our alternative to the extremes of historical realism or nihilsm is a theoretical positioning we have come to call relationalism (for a full discussion see Durepos and Mills, 2012a, 2012b), which takes as its foundation an ontological stance that avoids the forced epistemic duality of either having one history based upon an empirically justified scientific formulation (Iggers, 1997) or a full plurality of histories and decent into postmodern relativism (Lang, 1997; Jenkins, 1997a). We acknowledge the 'reality' out there, while at the same time, because narratives do matter (Boje, 1991), recognize that the ways of constructing history as inscribed knowledge are multiple (Durepos and Mills, 2012a). By drawing upon elements of poststructural narrative historiography (Jenkins, 1991; Munslow, 2010) and Actor-Network Theory (Latour, 2005) we develop an ontological perspective that orders the researchers gaze toward the relations established, between persons, events and activities in the present and those of the past: relations in which we can acknowledge the empirical nature of a lived reality, material existence and the agentive nature of narrative in history while remaining epistemologically skeptical concerning the meanings and interpretations which get attached to the past through the construction of narrative.

To surface the problem of the-past-as-history and MOS and reveal some of the contours of a relational approach to understanding histories, we draw on representations of Max Weber. Our point here is not to review Weber in MOS, but to explore the representations of his work as forms of knowledge located in MOS histories and, second, to examine the role of conceptualizations of the 'past' and 'history' in the development of those representations. Finally, we wish to use the various representations of Weber to underscore the problematics of historical realism thus, hopefully, opening the historic turn to a more relational yet skeptical approach. To highlight the disjunctive nature of the past and the difference between the past and historical representation, we re-present our analysis in a non-linear chronological ordering; beginning in the proximal narratives, then the most distal and, finally, returning to the 'middle' narratives. With each of these conditionals and clarifications in mind, and for the purposes of this history, the results of our analysis are presented and discussed in the sections that follow. 


\section{Mad Max I: a history of sorts}

In undertaking the representation of the past we start at the end of history, or, in what is more commonly referred to as now. It is a career stage best characterized as the rethinking of Max Weber. In purely factual terms, we 'know' that Max Weber was born in 1864 and died in 1920 and that he wrote extensively on a range of issues that, arguably, were ideally suited to inform various understandings of the characteristics of management and organization in (post) industrial society. Yet, according to several recent accounts, much of Weber's work singularly centres on bureaucracy, and even then of a very narrow, mostly descriptive kind (Clegg and Lounsbury, 2009; Cummings and Bridgman, 2011). This renewed interpretation is taken from the retrospective creation of a previous and somewhat tarnished 'golden age' for Weberian theory in MOS; one where Weber's broader socio-political ideas of bureaucracy were first explored in a number of debates which then became embedded in various 'schools of thoughts' such as Contingency Theory (Pugh and Hickson, 1976) and New Institutionalism (DiMaggio and Powell, 1983) — (see Clegg and Lounsbury, 2009; Lounsbury and Carberry, 2005).

Nonetheless, mainstream and critical MOS theorists alike continue to refer to Weber as the 'founding father of organizational theory' (Lounsbury and Carberry, 2005: 501; Wren and Bedeian, 2009: 233). This constitutes a kind of second dimension of Weber's extant MOS career, namely, that for some time now he has been constituted as the founder of modern organization theory (Wren and Bedeian, 2009, our emphasis) or, more specifically, the founding father of bureaucracy (Bateman and Zeithaml, 1990; Bobbitt et al., 1974; Davis, 1967; Koontz et al., 1980; Robbins and Judge, 2008), 'the bureaucratic model' (Hellreigel and Slocum, 1974: 50) and even 'modern bureaucracy' (Gram, 1986).

In many of these accounts Weber is presented as a contemporary of Taylor, the Gilbreths, Fayol and other 'classic' theorists. Whether intended or not we gain the impression that Weber, Taylor and these others not only constituted MOS as a discipline-but also that the discipline of MOS (OT, OB, Management and related sub-disciplines) was constituted through their various activities. Wren (1979), for example, states that 'the life and work of Max Weber ... run chronologically parallel to that of Henri Fayol and Frederick Taylor' (p. 249). While Fayol contributed to 'the principles and elements of management', Weber's theory of bureaucracy was the outcome of his 'search for a blueprint of idealized structural arrangements ... and technical efficiency' (Wren, 1979: 253). This account stands in contrast to others that claim that Weber did not have any notable influence on MOS until at least the late 1940s. In this latter historical representation the 'father' of Organization Theory did not arrive on the scene until after the establishment of the field. For example, Dessler (1976: 30) points out that Weber's work was unknown to management theorists until the 1930s and even then was not influential until after it was later 'translated and published in America in 1947' (see also Filley et al., 1976; Gordon et al., 1990: 32). More recently, Clegg and Loundsbury (2009) contend that Weber essentially did not exist for management and organizational scholars until his 'discovery' by Talcott Parsons. It the perseverance of Parsons, along with Merton, Mills, Gouldner and others, over two decad ho helps to create the notion of Max Weber as an historical figure within MOS. In short, from Clegg and Loundsbury's (2009) perspective it was the representations of Talcott Parsons, which helped to invent the idea of Max Weber, the organizational theorist.

\section{Enter stage left: meeting Weber}

The earliest locatable reference to Weber was in The English Historical Review of 1892, where Weber's 'Roman Agrarian History and its Significance for Public and Private Law' (1891) was 
reviewed (Anonymous, 1892). The next reference to Weber in journals was not until the late 1890s where the Quarterly Journal of Economics highlights Weber's exemplary work on agrarian economics (Loeb, 1897). Weber citations appeared next in the journal Science in a report on the Congress of Arts and Science, held in the US in 1904. A transcript of his 1904 presentation was subsequently published and Weber was introduced as an 'Author of History of Commercial Societies ... numerous articles in commercial and scientific journals ... Editor of Archiv fur Sozialwissenschaft' (Weber, 1906: 725). In the American Historical Review of 1915 (Westermann, 1915), Weber's method for the study of economics in history was portrayed as an empirical exemplar, one of only two articles in the previous three decades so recommended. Diehl (1923), in an article translated into English by Monroe, describes Weber as an economist and universalist scholar to the humanities. Alternatively, in a requiem publication dedicated to Weber by several leading German sociologists and economists, Hankins describes Weber as the 'epitome' of the best of German thinking on sociology (1924). Wirth, who would later become a noted sociologist of the Chicago School, declared that 'The best-known and certainly most quoted sociologist in Germany is Max Weber' (p. 464) and cited five separate Weberian works in their original German (Wirth, 1926). However, outside of German and nascent American sociological circles Weber would continue to be represented variously as historian, sociologist and objective economist (Reynard, 1925), but not an organizational scholar nor a proponent of management theory.

The 'plastic' nature of Weber and his work brings into question the influence of later works in the categorizing and claiming of Weber's work and its importance. DiPadova and Brower (1992), for example, claim that Lowell Bennion's doctoral dissertation on Weber's methodology (Bennion, 1933), was the first book length and systematic English translation of Weber' methodology. However, with only 100 copies ever published it did not receive the same degree of exposure as did later translations. The first full translation of a Weberian work itself, General Economic History, was completed by the institutional economist Frank Knights in 1927 (Weber, 1927). This was shortly followed, most notably, by Parsons' Translation of The Protestant Ethic and the Spirit Capitalism (Parsons, 1930). Parsons would commence to 'promote' Weber to the wider English speaking Academy with his introductory consideration of Sombart and Weber's conceptualization of capitalism in the Journal of Political Economy (Parsons, 1928). Prior to Parsons' translation of The Protestant Ethic and the Spirit Capitalism, this, along with two other of Weber's works, were already read and cited in their original German: in 1904 in the Journal of the Royal Statistical Society (Anonymous, 1904), in the Harvard Theological Review (Foster, 1908) and again in The Biblical World (Mathews, 1915). So, almost three decades prior to Parsons' translation, The Protestant Ethic was already considered a 'famous discussion of religion in relation to economic ethics and the coming of capitalism' (Plummer, 1928: 465). It would not be until later still, that Parsons would significantly revisit Weber's work with the publication of Structure of Social Action (Parsons, 1937).

Even then, Weber's scholarly persona remained somewhat ephemeral and unconsolidated, oscillating between economist and economics, historian and economic history, and finally, as a sociologist. One contemporary reviewer of Parsons' work referred to it as a study of an 'economist' (Crawford, 1938: 179-178) while another referred to it as a contribution to political-science (Catlin, 1939). In one of the first sociological texts written for students (Bogardus, 1929), there was no mention of Weber, yet in that same year Abel's (1929) Systematic Sociology in Germany, which included a relatively in-depth review of Weber, was credited as being important to the development of sociology in America (Becker, 1929): Halas (2002) would later claim that Abel's work was important in introducing the Weberian concepts of 'Verstehen' and 'Verstehende Soziologie' into the grammar of American sociology. By then Weber's presence in the sociological community was 
rapidly growing, with Weber described as an 'outstanding sociologist' (Ginsberg, 1932: 432) and with the use of Weber's Ideal-Typical Method, and its application within American-based sociology, preventing it from remaining 'provincial and barren' (Becker, 1934: 405).

Despite the growing recognition of Weber as a sociologist and his increasing presence in varied literatures of other disciplines, Weber, however, could not be located in the contemporary general management literature or texts of this time. This absence has potentially different implications for MOS histories depending on whether the origins of MOS are attributed to histories where disciplinary formation is located in a post-World War II America (Augier, 2008; Augier et al., 2005; March, 2005) or at the turn of the century (George, 1968; Khurana, 2007; Wren, 1972), particularly in light of Weber's 'place and standing' as attributed in more recent historical contexts. In the case of the former it is quite plausible to view Weberian theory as contributing significantly to the field as the work was known, while in the case of the latter not so much!

\section{An actor's roles: Weber in MOS}

In the two decades following WWII, management scholars would draw heavily upon sociology, economics and psychology (Khurana, 2007) in order to legitimate management as an institution and field of study (Pierson, 1959). Thus, Weber arguably came into 'existence' in the management literature through sociology's influence. First, in texts that include Bendix (1945, 1946), Gerth and Mills (1946), Gouldner (1954), Merton et al. (1952), Parsons (1937), then by the nascent journal literature (Clegg and Loundsbury, 2009), before appearing in texts on the intellectual history of management (Wren, 1972) and finally in various management curriculum textbooks (e.g. McFarland, 1964). The growing Weberian presence occurred during the formalization of the field out of a multi-disciplinary chaos that involved numerous efforts to describe and shape the emerging terrain of the discipline (Kelley et al., 2006; Khurana, 2007).

Arguably, the growing acknowledgement of Weber as a foundational 'management thinker' was part of a broader process. It was one element in establishing the boundaries of the emergent field of MOS through various attempts to historicize its foundations (see, for example, Augier et al., 2005; Barley and Kunda, 1992; O'Connor, 1999; Shenhav, 1995, 2003; Shenhav and Weitz, 2000; Wren, 1972). Nonetheless, it would be some time before Weber gained general acceptance as a founding theorist. For example, Weber and his work remained absent from Urwick's (1956) account of the contributions of 70 significant management pioneers and in Heyel's even more comprehensive (1964) Encyclopedia of Management. This was similar to the absence of Weber in the field's nascent journal literature.

Amongst the first journal-based attempts to historicize the field were Koontz (1961) and Scott (1961) who in attempting to formulate a synthetic or disciplinary-based sense of order to the 'jungle' of management and organization study each explicitly addressed the formative history of management thought. Unlike the enumeration of specific persons as pioneers or founders, as storied in Heyel (1964) and Urwick (1956), both Scott and Koontz - while mentioning significant actorsapproached the ordering of management thinking from an intellectual perspective with various 'schools of thought' having distinct disciplinary-based predecessor characteristics and associated research methodologies or approaches. Scott categorized management thinking into three variants, Classical, Neo-Classical and Modern variants, while Koontz (1961) described six. While these articles were not designed to 'list' the contributory work of scholars, numerous scholarly contributors were described. Weber was not one of them - even though significant emphasis was placed on the role of both economics and sociology; two of the dominant disciplinary descriptors given to Weber over the previous two decades. Both Scott (1974) and Koontz (1980) would later revisit 
their descriptions in revised and updated versions of their original articles. However, there would still be no mention of Weber or his contributions. This is seen as somewhat anomalous as by this time the management field had already seen the publication of two separate intellectual historiesboth of which included Weber and his contributions to management thought (George, 1968; Wren, 1972). Weber had by then entered the journal literature.

We will eschew a detailed description of journal citations of Weber in this period in the management, sociological and organizational theory literature as this has done at length elsewhere (Lounsbury and Carberry, 2005). However, we will briefly recapitulate several observations which we consider relevant to this analysis. First, citation of Weber was greatest in the sociological literature, followed by the European management literature, with the North American based general management literature citing Weber the least. Second, not only did the general management literature have fewer citations but it lagged behind the sociological by several years. Third, the overall pattern of citations of Weber peaked in the 1960s and has generally declined since, with only a brief resurgence in the late 1980s. Finally, the use or positioning of Weber's theory was treated differently by the various sub-specialties citing Weber's work, e.g. specialties focused on inter-organizational perspectives versus an organization-environment focus.

Within textbooks one of the earliest reference to Weber was in the period where management was most heavily drawing upon its predecessor disciplines and most tightly focused on the issue of business and bureaucracy (McFarland, 1964). Weber was described as a German Sociologist who was 'the first [scholar] to develop a systematic concept of authority in bureaucratic organizations', viz. The Theory of Social and Economic Organization (Weber, 1947). This is a pattern that would be repeated in many of the subsequent management texts published in the following three decades. A slow process of convergence in representational stereotype through an accrual of narratives which would come to dominate Weberian descriptions found in the textbook; one where he is most often historically positioned as a founding figure of management and organization studies (see, for example, Greenberg et al., 2000; Magnusen, 1977; Moorhead and Griffin, 1998).

\section{Reading Weberian histories in the past}

The various representations of Weber in MOS suggest multiple alternative historical career traces. Unfortunately these differences are rarely noticed and where they are they have often been linked to such things as issues of translation (Baehr, 2001; Clegg and Lounsbury, 2009), a failure to read Weber in context (Bendix, 1974) and/or a failure to sufficiently historicize MOS in general or Weber in particular (Cummings and Bridgman, 2011) rather than to any problematic concerning the difference between the past and history. Let us examine each issue in turn. For the 'politics of translation' (Clegg and Lounsbury, 2009: 123), it has been argued at great length that much of what we have come to know of as key aspects of Weber's work, particularly The Theory of Social and Economic Organization and The Protestant Ethic and the Spirit of Capitalism, relied on Parsons' translation. For a vast array of MOS scholars this did not seem to be an issue as it was accepted as the simple process of taking words that more or less represent reality in one language and translating them into another. Errors, it might be supposed, could be rectified when needed by reference to the 'real' meaning of the original author. However, as Baehr (2001) explains, it is not that simple, as words develop in a socio-historical context and their translation is influenced by the socio-historical location of the translator, where there is ' a transformation of ideas, styles of thinking, modes of expression, indeed a whole context of mental imagery and assumptions many of which may be unnoticed by the writer, the translator, and the reader' (Hinkle, 1986 cited in Baehr, 2001: 155). 
Thus, Baehr (2001) shows how the canonical phrase 'Iron Cage of Bureaucracy' is actually a misreading of a more profound and intended metaphor of bureaucracy — a 'shell as hard as steel'. It was not, according to Baehr (2001), a simple error of description: while an 'iron cage' suggests some sense of imprisonment of the self, the steel shell was meant to refer to a profoundly changed self that has metamorphosed into a different way of being. Drawing on Hinkle's (1986) idea of the 'Americanization' of Weber's work, Baehr (2001) goes on to discuss other such errors of translation (e.g. in Gerth and Mills, 1946) and concludes that 'the first duty of the translator is to be faithful to the author' (p. 168). In a similar vein, Clegg and Lounsbury (2009) describe and explain Parsons' (problematic) translation in terms of his authorial commitment to functionalism and the Cold War context in which he was developing his later theories. Consequently, they call for 'a deeper engagement with Weber's scholarship [that] can expand the scope of current organizational analysis' (p. 118) and allow 'organization theory [to] reclaim Weber as a scholar of domination for a discourse whose translations of Weber ... are more useful and useable' (p. 139).

This resurfaces the pressing issues of context as Baehr (2001), Clegg and Lounsbury (2005) and others suggest that context influences translation. The point is made at length by Bendix (2005) who argues that analysis of bureaucracy or any 'large-scale organization', must always take into account

a) the social and ideological background of a diversity of persons ... b) the institutional setting in which the organization must function and its effect on the psychology of internal operation [and] c) the historical and psychological context in which the people outside the organization view its activities. (p. 494)

In a later reiteration of this point, Bendix (1974: 245) uses a critique of Gouldner's (1956) reading of Weber to make the point that: 'To use Weber's concepts outside this context requires a reinterpretation; otherwise Weber's intentions as well as his contribution to knowledge are distorted and easy to criticize ...' .

This returns us to the issue of past-as-history and historical context, as raised in Bendix's 1947 article. It is a cry taken up by Cummings and Bridgman (2011: 77) who argue that a critical approach to history is of value for present day management education. By way of illustrating their point, they undertake analysis of 'the representation of Max Weber in management texts' using a set of Foucauldian methods. They conclude that historical awareness is needed to overcome the 'wrong-headed configuration of Weber' in management texts even while ignoring the fact that these versions of Weber are those which also comprise the history of Weberian interpretation in MOS.

Each of these authors makes detailed and reasoned arguments that we are sympathetic to. We do feel that Weber has likely been badly translated at various times, that he should be read in context and that greater attention to historical processes are required. Nonetheless, we are also simultaneously concerned by what appears to be the ontological trap contributing to a continued ignorance of the various pleas for a more interpretive approach to MOS (and, in a contrawise fashion, lead to the further strengthening of basic realist and scientistic accounts of MOS, past and present). We base our argument on the following claims.

First, the past has gone and cannot be reproduced. Regardless of the lives of materially real people that existed prior to now, representations of those lives are not themselves the reality they purport to represent. All of the discussions of Weber that we have reviewed resort at some point or another to a claim of representing the real Max Weber; be it a reference to Weber as the proponent of efficiency (Wren, 1979), the contextualized (Bendix, 1974) or a more historically correct (Cummings and Bridgman, 2011) Weber. Second, representations of the past are founded upon a 
series of literary (e.g. narrative style), psychological (e.g. the choice made by the author) and socio-political (e.g. influences on the author, the subject and the dissemination of the associated ideas) factors. That is, from a population of potentially innumerable theorists, someone or other had to make the choice to bring Weber to the attention of MOS theorists. The surfacing of Weber's work by various actor and actor-networks involved not only a selected range of his work but also a selection of the internal specifics of his particular writings. The presentation of these selected elements and interpretations of Weber's work relied on choices of narrative style to bring the 'facts' to life, e.g. Weber the apostle of efficiency or the victim of scholarly neglect. Following these choices, the crafting of history by subsequent other communities of practice (Clegg and Lounsbury, 2009) or actor networks (Latour, 2005) then play their additional part in the further dissemination of these selected ideas accruing even more.

For those with a direct interest in history and MOS, these past events have been presented as 'recovery' through various excavations; revealing the role of Weber in the making of our field of endeavour. What remains masked in each recovery is the author's own role; not only in determining which events, people, and timeframes constitute something called MOS, but also in the creation of MOS as an historical phenomena itself (see, for example, Wren, 1979; Wren and Bedeian, 2009). This is likely not the type of 'attentiveness to historical processes' that Cummings and Bridgman, (2011) had in mind. Yet, even though we can admit that the past once existed - one where real people lived real lives - it, the 'past,' does not have 'a continuing "material" presence' (Munslow, 2010: 2) into the present. It is a different category of experience from 'history' and thus 'has considerable consequences for historical thinking and practice' (Munslow, 2010, p.37). The 'past', contrary to what the debates around issues of translation seem to suggest, does not reside in some empirically verifiable form of words that mirror the past. There is no reality-correspondent 'truth' of the past. Rather the words first ite and thus constitute the past. Historical 'truth (what the past was and what it meant) mean come down to what "appears to be the case" from the historian's perspective' (Munslow, 2010: 49). In short, no description of the past 'can escape its epistemic status as a figurative and expressive mediation to which the author-historian's aesthetic and ethical judgements are central' (Munslow, 2010: 7).

Even those scholars whose work has no particular focus on the past-as-history still invoke the past, either directly or indirectly, to concretize their message when claiming that the past has spoken, that people and events are established facts and that it is time to move forward with that knowledge. The past-as-history means tha need not further concern ourselves with its meaning, as meanings ar $D$ levant in the preserm, nobbins (1997, cited in Cummings and Bridgman, $2011,77)$ argues th tudents want to know what works and what doesn't ... they are not interested in the historical evolution or our knowledge'. This declaration evokes notions of a fixed past that has somehow (verifiably) contributed to the present in an almost continuous stream of knowledge production. Similarly, for many MOS scholars who reference Weber and his theory of bureaucracy, it is as if what is being said are somehow historical facts, rather than representations, debatable only in the details!

Even critiques of MOS accounts of Weber tend to evoke problematic rather than problematized notions of the 'past'. We might ask, for instance, given the role of language in mediating the 'past', how do we decide what is a 'faithful' translation of an author's intent? Given the various (concepts of) processes (e.g. biographical, organizational, cultural, economic, political) that are said to influence human existence what is there to help us decide what constitutes the 'context' in which Weber lived? Given that the 'past' can only ever be represented through such things as tropes, narrative style and pre-figured order (Foucault, 1972: White, 1973, 1985) how do we decide what counts as an appropriate historical process? The answers to these questions are problematic and left unasked 
often lead us to default to foundational claims of a 'real' past, where perhaps a 'better' Weber is waiting to be uncovered/discovered. In MOS' turn to history, these issues remain problematic, as we shall argue, and ultimately serve to undermine arguments for more critical accounts of MOS. As Munslow (2010: 2) puts it, while we can 'presuppose the existence of a past' we should 'also acknowledge the problems involved in describing/inscribing it as "history" (p. 2). Something which we collectively do not currently do!

\section{Mad Max II: the return of Martin Guerre}

After years of living with certain versions of Max Weber in MOS, a number of recent accounts have attempted to herald the return of a different, more rounded and more profound Max Weber. A Weber who is perhaps more comfortable in a new postpositivist (Prasad, 2005) surrounding than the older, more positivist, version (Burrell and Morgan, 1979). Like the story of Martin Guerre (Davis, 1983), we are asked to believe in the new Max Weber-but we can't reference any foundationally-based evidence of this as 'we cannot demonstrate in and through our histories that we have the basis for "true" knowledge about what the past did mean' (Munslow, 2010: 4). However, Munslow (2010: 46-53) offers a way out of the conundrum through what he calls 'multiple skepticism'. What this means is that we can accept that things (people, their interactions, and accounts of those lives) existed before now. For example, we can certainly claim with some verifiable accuracy that Max Weber existed in the past, and that he was the author of certain texts. We may therefore accept that it is a reasonable expectation that an historical account be about things that must have existed and taken place (Veyne, 1984). However, acceptance of either of these tenets does not imply an acceptance that somehow a history is 'real' and that the past can be more or less accurately represented through it. For "skeptical historians are likely to doubt the knowability of "the" meaning of the past because ... the past does not exist (i.e. is known before it is "(hi)storied" (Munslow, 2010: 3-4). Thus, a skeptical approach is one that presupposes the existence of a past but also acknowledges the "problems involved in describing/inscribing it as "history"' (Munslow, 2010: 2).

\section{Towards an epistemic phase of the historical turn}

The primary 'grounding' for a skeptical approach is ethics and aesthetics; a self-consciously ethical position that views 'the production of knowledge about the past' not as an end in itself, but as a way of disrupting 'the certainties of the present and so [opening] the way to imagining a different future' (Scott, 2006, quoted in Munslow, 2010: 70: see also Booth and Rowlinson, 2006; Jacques, 1996 who make very similar points). The issue of aesthetics is summed up nicely by Jenkins (1997b: 62), who argues that

historiography — despite its sometime empirical features - is, in the forming of its 'narrative substances' $\ldots$ an aestheticising practice. Accordingly, because aesthetics are not subject to true/false interrogation ... such a discourse cannot logically support true/false 'significations' beyond the level of the statement or the chronicle.

Quite simply, yet profoundly, a skeptical historian understands that, to paraphrase Weick (1995), historical narratives can only be about their plausibility rather than any correspondent measure of accuracy.

MOS is a discourse 'constituted by a matrix of texts, theories, concepts, practices and institutional forms and arrangements' (Westwood and Clegg, 2003: 1). Much of the matrix is inscribed in 
and constituted by the narratives found in our journals and texts (whether presented as histories or not) and these are forms of discursive practice and instantiations of power (Foucault, 1980) in our field. They become the legitimating devices (Mumby, 1987) used to regulate the field as "what we create in language "uses us" in that it provides a point of view (a context) within which we "know" reality and orient our actions' (Boje et al., 2004: 571). Only by understanding the ontological differences between representations of the past, historical narratives and the irrecoverable and unknowability of the past reality of the world, can we begin to see that the present epistemic configuration of the 'matrix' that is MOS is the result of our ordering of history-not of any past comprised of a series of present moments where we collectively argued that 'this is the way it is' based upon the past-as-history logic of the 'this is the way it was'!

As we have shown in the various representations of Weber, including the histories of Weber constructed over time, Weberian narratives are the results of the 'interests' of the various communities of practice or actor-networks established in relation to their own projects, their of $P$ chools or their own perspectives. These relations are both created by these actors and network, ror we are all historians (Geary, 2008), as much as they are mediated by how our histories portray and interpret Weber and his work. Thus, the mutability of Weber and Weberian theory is the result of the ongoing process of subsequent and iterative re-interpretation of Weber as scholars, situated in one socio-political moment, move between their present projects and Weberian historical traces in another socio-political moment. The implication from this view is that a 'Parsonian' Weber cannot be any less, nor any more, 'truly' Weberian than a 'Bendixian' (Bendix, 1960), 'Cleggian' (Clegg and Lounsbury, 2009) or 'Shenhavian' (Shenhav, 2003) version. Each representation is, at its most fundamental, an historical interpretation of Weber's work made within a specific socio-political context and for a specific purpose. Each is one scholarly reading of Weber's theory, used in an attempt to persuade others of a specific point of view or perspective; philosophical, political, theoretical or methodological: a fluidity of meaning of interpretation when read in the present (Westwood and Clegg, 2003). In this respect, historical knowledge is always continuously emergent and historical awareness is the result of an ongoing process of oscillation occuring in the intellectual spaces opened up between an ever-shifting present and an unrecoverable past. Thus, relational views of history fosters skepticism by opening up history through multiple understandings of the past by allowing us to ask different questions than we otherwise may have as 'every way of seeing is also a way of not seeing' (Burke, 1935: 70).

For critical management scholarship the (skeptically) relationalist approach outlined here still poses various problems and challenges, not least of which is a renewed questioning of both realism and recent calls for a 'materialist turn' in MOS and relativist claims of a specifically individualist or discursive kind found in poststructuralist historiography. Thus, even while we draw on Munslow (2010), Jenkins (1997b) and other postructuralist historians for understandings of the past/history conundrum, our point of departure lies in the notion that historical accounts are always multiple and adjudicated by individual historians (Fish, 1994). We argue instead for an approach that draws on the sociology of knowledge to explain how history-as-knowledge held by a community is produced through an historicized actor network (Durepos and Mills, 2012b) that allows us to 'follow the actors' in the development of MOS and its history. In that process, our embedded critique of materialism should only be read as a question of balance and emphasis. We accept the ontological reality of people as material beings but contend that there are no epistemologically universal truths or projects of liberation embedded in these persons as 'facts' - or the past-ashistory perspective. Facts and narra prield only the potential for more or less plausible accounts within networks. For example, whil ful relational account of the development of Taylorism is grounded in realist notions of 
the prin of facts and a metaphysical notion of history as both real yet transcending human existen , $r$ us the liberationary potential lies in freeing human action from the burden of how we believe history while simultaneously retaining our ability to capture what is important through stories and narratives over time.

The project of history should be one of understanding and meaning-making as history is arguably one of the last, and most powerful, discourses to retain a hold on extant knowledge and our recourse to settle disputes by references to the 'past'. It permeates our arguments and thus sidesteps and avoids the critical gaze that we otherwise bring to all other aspects of the present and the capability to move understanding in new directions. Thus, we call for an approach to the development of critical organizational histories that at one and the same time exposes (and thus weakens) the socially assembled nature of history-as-knowledge, while continuing to value the character of narratives as multiple but not fully definitive. Developing a more critically oriented historical consciousness allows us to avoid the 'common-sense' trap of the conflation of the past with history. By recognizing the ontological difference between the 'past' and 'history' we can develop a more nuanced understanding of the productive and enactive dimensions of history-making in our research and surface the ontological politics of our work. A reflexively balanced historicizing process is one that remains cognizant of the interplay between the factive and narrative elements in our writing, acknowledges that history is neither singular and unitary nor plural and relative and stems from the relations of actors as they become networks (or vice versa) in a particular socio-political context. Taken together, we see this as an approach which allows MOS to more fully and more reflectively engage with History and history in answer to the $(10$ pr an 'Historic Turn': an approach that critically sets out to move forward the call for more plurar understandings of the past while not buying into the metaphysical notion of history as the arbiter of the past.

\section{References}

Abel, T. (1929) Systematic Sociology in Germany. New York, NY: Columbia University Press.

Ankersmit, F. R. (1998) 'Historical Representation', History and Theory 27: 205-28.

Anonymous (1892) 'List of Historical Books Reviewed', The English Historical Review 7: 193-201.

Anonymous (1904) 'Notes on Economic and Statistical Work', Journal of the Royal Statistical Society 67: $684-732$.

Augier, M. (2008) 'A Retrospective Look at A Behavioural Thoery of the Firm', Journal of Economic Behavior and Organization 66: 1-16.

Augier, M., March, J. and Sullivan, B. (2005) 'Notes on the Evolution of a Research Community: Organization Studies in Anglophone North America, 1945-2000', Organization Science 16: 85-95.

Baehr, P. (2001) 'The "Iron Cage" and the "Shell as Hard as Steel": Parsons, Weber, and the Stahlhartes Gehäuse Metaphor in the Protestant Ethic and the Spirit of Capitalism', History and Theory 40: 153-69.

Barley, S. R. and Kunda, G. (1992) 'Design and Devotion: Surges of Rational and Normative Ideologies of Control in Managerial Discourse', Administative Science Quarterly 37: 363-99.

Bateman, T. S. and Zeithaml, C. P. (1990) Management. Function and Strategy. Homewood, IL: Irwin.

Becker, H. (1929) 'Systematic Sociology in Germany by Theodore Abel', The ANNALS of of the American Academy of Political and Social Science 145: 206.

Becker, H. (1934) 'Culture Case Study and Ideal-Typical Method: With Special Reference to Max Weber', Social Forces 12: 399-405.

Bendix, R. (1945) 'Bureaucracy and the Problem of Power', Public Administration Review 5(3): 194-209.

Bendix, R. (1946) 'Max Weber's Interpretation of Conduct and History', The American Journal of Sociology 51(6): 518-26.

Bendix, R. (1960) Max Weber: An Intellectual Portrait. New York, NY: Doubleday and Company, Inc.

Bendix, R. (1974) Work and Authority in Industry. Berkeley, CA: University of California Press.

Bennion, Lowell L. (1933) Max Weber's Methodology. Paris: Les Presses Modernes. 
Bobbitt, R. H., Breinholt, R. H., Doktor, R. H. et al. (1974) Organizational Behavior Understanding and Prediction. Englewood Cliffs, NJ: Prentice Hall, Inc.

Bogardus, E. (1929) A History of Social Thought. Los Angeles, CA: University of Southern California Press.

Boje, D. (1991) 'The Storytelling Organization: A Study of Story Performance in an Office Supply Firm', Administrative Science Quarterly 36: 106-26.

Boje, D., Oswick, C. and Ford, J. (2004) 'Introduction to Special Topic Forum: Language and Organization: The Doing of Discourse', Academy of Management Review 29: 571-77.

Booth, C. and Rowlinson, M. (2006) 'Management and Organizational History: Prospects', Management and Organizational History 1: 5-30.

Brown, C.G. (2005) Postmodernism for Historians. London: Pearson.

Bryman, A., Bell, E., Mills, A. J. and Yue, A. R. (2011) Business Research Methods. First Canadian Edition. Toronto: Oxford University Press.

Burke, K. (1935) Permanence and Change: An Anatomy of Purpose. New York, NY: New Republic.

Burrell, G. and Morgan, G. (1979) Sociological Paradigms and Organizational Analysis, London: Heinemann.

Catlin, G. (1939) 'The Structure of Social Action by Talcott Parsons; Bio-Politics. by Morely Roberts', Political Science Quarterly 54: 264-66.

Clark, P. and Rowlinson, M. (2004) 'The Treatment of History in Organization Studies: Towards an "Historic Turn”?', Business History 46: 331-52.

Clegg, S. and Lounsbury, M. (2009) 'Sintering the Iron Cage. Translation, Domination, and Rationality', in P. S. Adler (ed.) The Oxford Handbook of Sociology and Organization Studies. Classical Foundations, pp. 118-45. Oxford: Oxford University Press.

Cooke, B. (1999) 'Writing the Left out of Management Theory: The Historiography of the Management of Change', Organization 6: 81-105.

Crawford, W. (1938) 'Structure of Social Action by Talcott Parsons', Annals of the Academy of Political and Social Science 198: 178-79.

Cummings, S. and Bridgman, T. (2011) 'The Relevant Past: Why the History of Management Should be Critical for Our Future', Academy of Management Learning and Education 10: 77-93.

Davis, K. (1967) Human Relations at Work: The Dynamics of Organizational Behaviour. New York, NY: McGraw-Hill Book Company.

Davis, N. Z. (1983) The Return of Martin Guerre. Cambridge, MA: Harvard University Press.

Dessler, G. (1976) Organization and Management A Contingency Approach. Englewood Cliffs, NJ: PrenticeHall Inc.

Diehl, C. (1923) 'The Life and Work of Max Weber', The Quarterly Journal of Economics 38: 87-107.

DiMaggio, P. J. and Powell, W. (1983) 'The Iron Cage Revisited: Institutional Isomorphism and Collective Rationality in Organizational Fields', American Sociological Review 48: 147-60.

DiPadova, L. and Brower, R. (1992) 'A Piece of Lost History: Max Weber and Lowell L. Bennion', The American Sociologist 23: 37-56.

Durepos, G and Mills, A. (2012a) ANTi-History: Theorizing the Past, history, and Historiography in Management and Organizational Studies: Information Age Publishing.

Durepos, G. and Mills, A. J. (2012b) 'Actor Network Theory, ANTi-History, and Critical Organizational Historiography', Organization, in press.

Fay, B. (2004) 'Introduction: Historians and Ethics: A Short Introduction to the Theme Issue', History and Theory 43: 1-2.

Filley, A. C., House, R. J. and Kerr, S. (1976) Managerial Process and Organizational Behavior, Glenview, IL.: Scott, Foresman and Co.

Fish, S. (1994) There's No Such Thing As Free Speech. New York, NY: Oxford University Press.

Foster, H. (1908) 'Calvin's Programme for a Puritan State in Geneva, 1536-1541', The Harvard Theological Review 1: 391-434.

Foucault, M. (1972) The Archaeology of Knowledge. London: Routledge. 
Foucault, M. (1980) Power/Knowledge: Selected Interviews and Other Writings 1972-1977. London: Tavistock.

Geary, D. (2008) 'Every Social Scientist Her Own Historian', Modern Intellectual History 5: 399-410.

George, C. (1968) The History of Management Thought. Englewood Cliffs, NJ: Prentice-Hall, Inc.

Gerth, H. and Mills, A. (1946) Max Weber: Essays in Sociology. Oxford: Oxford University Press.

Ginsberg, M. (1932) 'History and Sociology', Philosophy 7: 431-45.

Goldman, P. (1994) 'Searching for History in Organizational Theory: Comment on Kieser', Organzation Science 5(4): 621-23.

Gordon, J. R., Mondy, W. and Sharplin, A., et al. (1990) Management and Organizational Behavior. Boston, MA: Allyn and Bacon.

Goulder, A. (1954) Patterns of Industrial Bureaucracy. New York, NY: Free Press.

Gram, H. A. (1986) The Canadian Manager. An Introduction to Management. Toronto: Holt, Rinehart and Winston of Canada.

Greenberg, J., Baron, R. A., Sales, C.A. et al. (2000) Behaviour in Organisations. Scarborough: Prentice Hall Canada, Inc.

Halas, E. (2002) 'Ethical Dilemmas of "Verstehen" in Sociology: Theodore Abels' Encounter with Nazism', Polish Sociological Review 2: 173-87.

Hankins, F. (1924) 'Review: Hauptprobleme der Soziologie: Erinnerungsgabe fur Max Weber by Von Schulze-Gaevernitz, G. Sombart, W. and Others', Journal of Social Forces 2: 624.

Hellriegel, D. and Slocum, J. W. (1974) Management A Contingency Approach. Reading, MA: AddisonWesley Publishing Company

Heyel, C. (1964) The Encyclopedia of Management. New York, NY: Reinhold.

Iggers, G. (1997) Historiography in the Twentieth Century: From Scientific Objectivity to the Postmodern Challenge. Hanover, NH: Wesleyan University Press.

Jacques, R. (1996) Manufacturing the Employee: Management Knowledge from the 19th to 21st Centuries. London: Sage.

Jacques, R. (2006) 'History, Historiography and Organization Studies: The Challenge and the Potential', Management and Organizational History 1: 31-49.

Jenkins, K. (1991) Re-thinking History. London: Routledge.

Jenkins, K. (1997a) The Postmodern History Reader. London: Routledge.

Jenkins, K. (1997b) 'Why Bother with the Past? Engaging with Some Issues Raised by the Possible "End of History as We Have Known It"', Rethinking History 1: 56-66.

Jenkins, K. (2003) Refiguring History. New Thoughts on an Old Discipline. London: Routledge.

Kalela, J. (2012) Making History. The Historian and Uses of the Past. London: Routledge.

Kelley, E. S., Mills, A. J. and Cooke, B. (2006) 'Management as a Cold War Phenomenon?', Human Relations 59: 603-10.

Khurana, R. (2007) From Higher Aims To Hired Hands. The Social Transformation of American Business Schools and the Unfulfilled Promise of Management as a Profession. Princeton, NJ: Princeton University Press.

Kieser, A. (1994) 'Crossroads-Why Organization Theory Needs Historical Analyses-and How This Should Be Performed', Organization Science 5: 608-20.

Knights, D. (2002) 'Writing Organizational Analysis into Foucault', Organization 9: 575-93.

Koontz, H. (1961) 'The Management Theory Jungle', Journal of the Academy of Management 4: 174-88.

Koontz, H. (1980) 'The Management Theory Jungle Revisited', Academy of Management Review 5: $175-87$.

Koontz, H., O’Donnell, C. and Weihrich, H. (1980) Management. New York, NY: McGraw-Hill.

Lang, B. (1997) 'Is It Possible to Misrepresent the Holocaust?', in K. Jenkins (ed.) The Postmodern History Reader, pp. 426-33. New York, NY: Routledge.

Latour, B. (2005) Reassembling the Social. Oxford: Oxford University Press.

Law, J. and Mol, A. (1995) 'Notes on Materiality and Sociality', The Sociological Review 43: 274-94.

Loeb, E. (1897) 'The German Exchange Act of 1896', The Quarterly Journal of Economics 11: 388-428. 
Lounsbury, M. and Carberry, E. J. (2005) 'From King to Court Jester? Weber's Fall from Grace in Organizational Theory', Organization Studies 26: 501-25.

Lukacs, J. (1968) Historical Conciousness: Or The Remembered Past. New York, NY: Harper and Row, Publishers.

Magnusen, K. O. (1977) Organizational Design, Development and Behavior. Glenview, IL: Scott, Foresman and Co.

March, J. (2005) 'Parochialism in the Evolution of a Research Community: The Case of Organization Studies', Management and Organization Review 1: 5-22.

Mathews, S. (1915) 'Theology and the Social Mind', The Biblical World 46: 201-48.

McFarland, D. E. (1964) Management: Principles and Practices. New York, NY: The MacMillan Company.

Merton, R. K., Gray, A. P., Hockey, B. and Selvin, H. C., eds (1952) Reader in Bureaucracy. New York, NY: Free Press.

Mills, A. J. and Durepos, G. (2010) 'ANTi-History', in A. J. Mills, G. Durepos and E. Wiebe (eds) Sage Encyclopedia of Case Study Research, Vol. 1, pp. 26-29. Thousand Oaks, CA: Sage.

Mol, A. (1999) 'Ontological Politics: A Word and Some Questions', in J. Law J and J. Hassard (eds) Actor Network Theory and After, pp. 74-89. Oxford: Blackwell Publishing.

Moorhead, G. and Griffin, R. W. (1998) Organizational Behaviour. Boston, MA: Houghton Mifflin.

Mumby, D. (1987) 'The Political Function of Narrative in Organizations', Communication Monographs 54: $113-27$.

Munslow, A. (2010) The Future of History. London: Palgrave MacMillan.

O'Connor, E. S. (1999) 'The Politics of Management Thought: A Case Study of the Harvard Business School and the Human Relations School', Academy of Management Review 24: 117-31.

Parsons, T. (1928) "“Capitalism” in Recent German Literature: Sombart and Weber', Journal of Political Economy 36: 641-61.

Parsons, T. (1930) The Protestant Ethic and the Spirit of Capitalsim: St Leonards: Allen and Unwin.

Parsons, T. (1937) The Structure of Social Action: A Study in Social Theory with Special Reference to a Group of Recent European Writers. New York, NY: McGraw-Hill Book Company, Inc.

Pettigrew, A. M., Woodman, R. W. and Cameron, K. S. (2001) 'Studying Organizational Change and Development: Challenges for Future Research', Academy of Management Journal 44: 697.

Pierson, F. C. (1959) The Education of American Businessmen: A Study of Unviersity-College Programs in Business Administration. London: McGraw-Hill.

Plummer, A. (1928) 'General Economic History by Max Weber; Frank H. Knight', The Economic Journal 38: $462-65$.

Prasad, P. (2005) Crafting Qualitative Research. Working in the Postpositivist Traditions. Armonk, NY: M. E. Sharpe.

Pugh, D. S. and Hickson, D. J. (1976) Organisational Structure in its Context: The Aston Programme I. London: Saxon House.

Reynard, H. (1925) 'Review: Gesammelte Aufstze zur Soziologie und Sozialpolitik by Max Weber', The Economic Journal 35: 440-42.

Robbins, S.P. and Judge, T. A. (2008) Essentials of Organizational Behavior. Upper Saddle River, NJ: Pearson, Prentice Hall.

Rowlinson, M. (2004) 'Historical Perspectives in Organization Studies: Factual, Narrative, and ArcheoGenealogical', in D. E. Hodgson and C. Carter (eds) Management Knowledge and The New Employee, pp. 8-20. Burlington, VT: Ashgate Publishing Company.

Rowlinson, M., Stager Jacques, R. and Booth, C. (2009) 'Critical Management and Organziational History', in M. Alvesson, T. Bridgman and H. Wilmott (eds) The Oxford Handbook of Critical Management Studies, p. 582. New York, NY: Oxford University Press.

Rusen, J. (2004) 'Historical Consciousness: Narrative Structure, Moral Function, and Ontogenetic Development', in P. Sexias (ed.) Theorizing Historical Conscousness, pp. 63-85. Toronto: University of Toronto Press. 
Scott, W. (1961) 'Organization Theory: An Overview and Appraisal', The Journal of the Academy of Management 4: 7-26.

Scott, W. (1974) 'Organization Theory: A Reassessment', Academy of Management Journal 17: 242-54.

Shenhav, Y. (1995). 'From Chaos to Systems: The Engineering Foundations of Organization Theory, 18791932', Administative Science Quarterly 40(4): 557-85.

Shenhav, Y. (2003) The Historical and Epistemological Foundations of Organization theory: Fusing Sociological with Engineering Discourse. In: Tsoukas H and Knudsen C (eds) The Oxford Handbook of Organization Theory. Oxford: Oxford University Press, 183-209.

Shenhav, Y. and Weitz, E. (2000) 'The Roots of Uncertainty in Organization Theory: A Historical Constructivist Analysis', Organization 7(3): 373-401.

Urwick, L. (1956) The Golden Book of Management: A Historical Record of the Life and Work of Seventy Pioneers. London: Newman Neame Limited.

Usdiken, B. and Kieser, A. (2004) 'Introduction: History in Organization Studies', Business History 46: 321-30.

Veyne, P. (1984) Writing History: Eassay on Epistemology. Manchester: Manchester University Press.

Weatherbee, T. (2012) 'Caution! This Historiography Makes Wide Turns: Historic Turns and Breaks in Management and Organization Studies', Management and Organzational History 7: 203-18.

Weatherbee, T. G., Durepos, G., Mills, A. J. and Helms Mills, J. (2012) 'Theorizing the Past: Critical Engagements', Management and Organizational History 7(3): 193-202.

Weber, M. (1906) 'The Relations of the Rural Community to Other Branches of Social Science', in J. Rogers (ed.) Congress of Arts and Science Universal Exposition St. Louis, 1904, pp. 725-46. New York, NY: Houghton Mifflin and Co.

Weber, M. (1927) General Economic History. London: George Allen and Unwin, Ltd.

Weber, M. (1947) Theory of Social and Economic Organization. New York, NY: Oxford University Press.

Weick, K. E. (1995) Sensemaking in Organizations. London: Sage.

Westermann, W. (1915) 'The Economic Basis of the Decline of Ancient Culture', The American Historical Review 20: 723-43.

Westwood, R. and Clegg, S. (2003) 'Introduction: The Power and Politics of Organiztaion Studies As A Discourse', in R. Westwood and S. Clegg (eds) Debating Organization: Pooint-Counterpoint in Organization Studies. Oxford: Blackwell Publishing Ltd.

White, H. (1973) Metahistory: The Historical Imagination in Nineteenth-Century Europe. Balitimore, MD: The Johns Hopkins University Press.

White, H. (1985) Tropics of Discourse. Essays in Cultural Criticism. Baltimore, MD: Johns Hopkins University Press.

Wirth, L. (1926) 'Topical Summaries of Current Literature: Modern German Conceptions of Sociology', The American Journal of Sociology 32: 461-70.

Wren, D. (1972) The Evolution of Management Thought. New York, NY: The Ronald Press Co.

Wren, D. (1979) The Evolution of Management Thought. New York, NY: Ronald Press.

Wren, D. and Bedeian, A. (2009) The Evolution of Management Thought. Hoboken, NJ: John Wiley and Sons, Inc.

Zagorin, P. (1999) 'History, the Referent, and Narrative: Reflections on Postmodernism Now', History and Theory 38: 1-24.

Zald, M. N. (1993) 'Organization Studies as a Scientific and Humanistic Enterprise: Toward a Reconceptualization of the Foundations of the Field', Organization Science 4: 513-28.

\section{Dingraphies}

ance Weatherbee is an Associate Professor of Management at the FC Manning School of Business at Acadia University in Wolfville, Nova Scotia, Canada. His primary academic interest is on the historiography of management thought and organization theory, specifically their instantiation as historical representations. His publications, amongst others, have appeared in Management and Organizational History, Management Decision, Culture and Organization, Organizational Research Methods and the Canadian Journal of 
Administrative Sciences. He attempts to remain as active as possible in selected conference venues, whether presenting, attending or organizing. He is currently co-editing an academic handbook focused on the intersection of Management and Organization Studies and History due for release in 2014.

Gabrielle Durepos is an Assistant Professor at the Gerald Schwartz School of Business, St Francis Xavier University, Canada. Her co-authored book ANTi-History: Theorizing the Past, History, and Historiography in Management and Organization Studies, seeks to address the call for an historic turn. She is a co-editor of both the Sage Encyclopaedia of Case Study Research as well as the Sage Major Work on Case Study Methods in Business Research. Her recent publications appear in Management and Organizational History, Journal of Management History, Critical Perspectives of International Business and Organization. She is currently engaged in an organizational history of a provincial museum complex in Nova Scotia, Canada.

Q ert J Mills is Director of the PhD (Management) and Professor of Management at the Sobey School of Business, Saint Mary's University, Canada and a Senior Research Fellow at Hanken University, Finland. His 34 books and edited collections include Sex, Strategy and the Stratosphere (Palgrave/MacMillan, 2006), ANTi-History: Theorizing the Past, History, and Historiography in Management and Organizational Studies (IAP, 2012, with Gabie Durepos) and the forthcoming Routledge Companion to Management and Organization History (with Trish McLaren and Terry Weatherbee). He has presented his work on historiography, critical sensemaking, gender and identity work at a number of conferences and in various journals. Albert serves on several editorial boards, including Management and Organizational History and Gender, Work, and Organization (Associate Editor). He is current a member of the International Critical Management Studies Board, and was previously the co-divisional Chair of the Critical Management Studies Division of the Academy of Management. Address: Sobey School of Business, Saint Mary's University, 903 Robie Street, Halifax, Nova Scotia, Canada B3H 3C3. 